\title{
GROWING ONE AND HALF YEAR-OLD SEEDLINGS OF MULBERRY HYBRIDS IN THE CONDITION OF KASHKADARYA REGION
}

\author{
Vokhobjon Karimovich Rakhmonberdiev \\ Candidate of Agricultural Sciences, Docent of the Department Sericulture and Mulberry Growing, \\ Tashkent State Agrarian University, Tashkent, Uzbekistan
}

Narzulla Orolovich Rajabov

PhD on Agricultural Sciences, Docent of the Department Sericulture and Mulberry Growing, Tashkent State Agrarian University, Tashkent, Uzbekistan

Khurshida Pardaevna Fozilova

Master Student on Sericulture Specialty, Department of Sericulture and Mulberry Growing, Tashkent State Agrarian University, Tashkent, Uzbekistan

Article DOI: https://doi.org/10.36713/epra3956

\begin{abstract}
In the article the problem of growing one and half year old seedlings of hybrids of mulberry tree has been described in the condition of Kashkadarya region. It has been reported that in mid-salted gray soils of Karshi steppes under summer sowing levels in the second year plantings it was more useful to rejuvenate them by leveling system above the soil till the beginning of vegetation. Herein, mineral fertilizers are applied twice at the rate of $240 \mathrm{~kg}$ of nitrogen, $90 \mathrm{~kg}$ phosphorus, and 45 potassium per ha that allow to obtain more quantity of seedlings and nursery plants of mulberry free.

KEYWORDS: Mulberry tree, seeds, seedlings, nursery plants, root crown, plantation, cultivation, irrigation, shoots, fertilizer, germination, hybrid, survival.
\end{abstract}

\section{INTRODUCTION}

In the Decree of the President of the Republic of Uzbekistan No.PP-2856 "On measures for organizing the activities of the Uzbekipaksanoat Association" dated March 29, 2017 and PP-2460 "On measures for the development and reform of agriculture in 2016-2020" dated December 29, 2015 and Decree of the Cabinet of Ministers of the Republic of Uzbekistan No. 616 "On the program of measures for the integrated development of the silkworm industry in 2017-2020" dated August 11,2017 , the breeders of Uzbekistan were assigned with certain tasks on creating new highly productive varieties and hybrids of mulberry with high farm valuable traits.

The requirements of the silk industry in recent years are increasing more and more, and the production of high-quality cocoon raw materials in the republic is becoming increasingly important. And, accordingly, at present, it is necessary to create a sufficient feed base, using new varieties of mulberry with high indicators of leaf yield and with increased nutritional properties.

Multifaceted researches in this sphere were carried out by the following scientists M.I. Grebinskaya, S. S. Zinkina, O. Pulatov, U. Kuchkarov, K. R. Rakhmonberdiev, M. Khibbimov.

The cultivation of one and a half year old seedlings is economically profitable and has been practiced for several years, however, in the literature there are almost no instructions on the agricultural practices of their growing.

In nurseries, the cultivation of mulberry seedlings is widely practiced by the way of summer sowing of seeds in June, July and even the beginning of August. Seedlings until the end of the growing season basically do not reach the standard rate and are left to grow 


\section{SJIF Impact Factor: 6.260| ISI I.F.Value:1.241| Journal DOI: 10.36713/epra2016 EPRA International Journal of Research and Development (IJRD)}

Volume: 5 | Issue: 1 | January 2020

- Peer Reviewed Journal

further for the second year. So, they are called one and a half year old seedlings. Their height reaches to 80-150 $\mathrm{cm}$, the diameter of the root crown is $0.9-1.4 \mathrm{~cm}$. Such plants lay down bush plantations and multi-row line bush plantings of mulberry trees along the roads, irrigation ditches and along the edges of cotton field cards. Thus, in a year and a half they get powerful and strong planting material.

\section{MATERIALS AND METHODS}

The second year seedlings are given free growth in the nursery, two inter-row cultivations and four to six irrigations during the growing season are carried out. Before and after outplanting, the lateral shoot is cut to the ring. Outplanted seedlings are sold to other farms. However, under this agricultural cultivation technique, the yield of one and a half year seedlings of 1 ha of the sowing section is very low and does not exceed 356.0 thousand pieces.

During the winter period, $60-90 \%$ of the stem length of summer seedlings freezes, and in the second year of vegetation the seedlings grow more by forming side shoots. To find out the reasons for this phenomenon and develop more perfect way to grow one and a half year old seedlings this research was conducted by us.

\section{RESULTS AND DISCUSSION}

In the first variant, the aerial part of the seedling was cut at the soil level in early spring. Seedlings received two cultivations, seven to nine irrigations and mineral fertilizers at the rate of: $240 \mathrm{~kg} /$ ha of nitrogen, $90 \mathrm{~kg}$ phosphorus and $45 \mathrm{~kg}$ potassium per ha. Half of the nitrogen rate was applied immediately after the pruning of plants, and all phosphorus, potassium with the rest $50 \%$ of nitrogen was used after $40-45$ days from the first term.

In the second variant (control), the seedlings freely grew and were cultivated according to the technology generally adopted in nursery farms. They were cut above the root crown. The experiment was carried out on mulberry tree hybrids (Zymostoiky $\times$ Pionersky, Karshi $1 \times$ Pionersky, Saniish-15 $\times$ Pionersky).

The seeds were sown on June 13-25 under a twotape method on the beds of $90 \mathrm{~cm}$ width. In the first year of vegetation, the seedlings received five to six irrigations and mineral fertilizers (in June) at the rate of $60 \mathrm{~kg}$ of nitrogen and $45 \mathrm{~kg}$ Phosphorus per ha.

Germination of seeds of summer sowing in the field depending on the hybrid combination and conditions of the year, ranged from $21.1 \%$ to $26.3 \%$. Much higher percentage of seed germination (26.3) was observed in the hybrid combination Karshi-1 $\times$ Pionersky and lower indication was in hybrid Zymostoiky $\times$ Pionersky (21.1). The survival of seedlings at the end of the growing season in the first year constituted $44.8-56.3 \%$ of germination, 1 ha of the sowing section kept 523-833 thousand plants with 60 thousand seeds at sowing in each variant (Table 1).

Table 1

Germination of seeds and survival of mulberry seedlings of summer sowing

\begin{tabular}{|l|c|c|c|c|}
\hline \multirow{2}{*}{ Hybrid } & \multicolumn{2}{|c|}{ Germination } & Survival, \% & $\begin{array}{c}\text { Number of seedlings } \\
\text { per ha thous. pcs }\end{array}$ \\
\cline { 2 - 3 } & Thous. pcs & \% & & 833,0 \\
\hline Karshi-1 $\times$ Pionersky & $15,8 \pm 0,75$ & 26,3 & 56,3 & 630,0 \\
\hline Saniish-15 $\times$ Pionersky & $13,4 \pm 0,98$ & 24,4 & 49,2 & 523,0 \\
\hline Zymostoiky $\times$ Pionersky & $12,6 \pm 1,1$ & 21,1 & 44,8 & 8 \\
\hline
\end{tabular}

The growth of seedlings of summer sowing at the end of the vegetation in the first year of cultivation reached to $12.3-71.0 \mathrm{~cm}$ (an average of $38-56 \mathrm{~cm}$ ) depending on the density of plants, $30-60 \%$ of seedlings were characterized with minimal growth. With increasing density of plants, the number of low growth and thin seedlings increases. In this state, the seedlings of summer sowing wintered. In the spring of next year,

Table 2

before the distribution of seedlings by variants, their survival was taken into consideration.

$11-14 \%$ of seedlings died during the winter period due to weather conditions, plant density, and biological properties of the hybrid combination. Particularly, high percentage of died seedlings (14) is observed in the hybrid combination SANIISH-15 $\times$ Pionersky, lower percentage (11) in the hybrid Zymostoiky $\times$ Pionersky (Table 2).

Survival of seedlings of summer sowing after wintering

\begin{tabular}{|c|c|c|c|c|}
\hline \multirow[b]{2}{*}{ Hybrid } & \multicolumn{3}{|c|}{ Number of observed seedlings } & \multirow{2}{*}{$\begin{array}{l}\text { Number of live } \\
\text { seedlings per ha } \\
\text { thous.pcs. }\end{array}$} \\
\hline & $\begin{array}{c}\text { Total } \\
\text { thous.pcs }\end{array}$ & live $\%$ & died \% & \\
\hline Karshi-1× Pionersky & 8,1 & 86,4 & 13,6 & 725,0 \\
\hline Saniish-15 × Pionersky & 6,04 & 86,0 & 14,0 & 542,0 \\
\hline Zymostoiky $\times$ Pionersky & 5,0 & 89,0 & 11,0 & 464,0 \\
\hline
\end{tabular}


After wintering period, 464-725 thousand seedlings remained on 1 hectare of the sowing section. The stem of $91.5 \%$ of living plants froze.

Consequently, the seedlings pruned above soil level, renewed growth from the remaining one or three buds after a week.
In pruned seedlings, regeneration is stopped if a zone below the root crown was also covered during pruning. At first, they grew slower than uncut plants, and by mid-summer they reached to their growth (Table 3).

Table 3

Regeneration ability and growth of hybrid seedlings in sowing section after cutting above soil

\begin{tabular}{|c|c|c|c|c|c|}
\hline \multirow{2}{*}{ Hybrid } & \multirow{2}{*}{$\begin{array}{c}\text { Number of } \\
\text { plants under } \\
\text { experiment } \\
\text { thous. pcs }\end{array}$} & \multicolumn{2}{|c|}{$\begin{array}{l}\text { Number of seedlings } \\
\text { forming regenerates }\end{array}$} & \multirow{2}{*}{$\begin{array}{c}\text { Height of one } \\
\text { and half year } \\
\text { old seedling, } \\
\mathrm{cm}\end{array}$} & \multirow{2}{*}{$\begin{array}{c}\text { Diameter of root crown } \\
\text { as on } 30 / \mathrm{IX}, \mathrm{cm}\end{array}$} \\
\hline & & $\begin{array}{l}\text { Thous. } \\
\text { pcs. }\end{array}$ & $\%$ & & \\
\hline Karshi-1× Pionersky & $3,5 / 3,5$ & $3,5 /-$ & $100,0 /-$ & $185,5 / 144,4$ & $1,70 \pm 0,07 / 1,35 \pm 0,09$ \\
\hline Saniish-15 × Pionersky & $2.6 / 2.6$ & $2,537 /-$ & $97,6 /-$ & $176,0 / 158,5$ & $164 \pm 0,11 / 1,30 \pm 0,08$ \\
\hline Zymostoiky $\times$ Pionersky & $2.22 / 2.22$ & $2,131 /-$ & $97,6 /-$ & $144,0 / 133,0$ & $1,32 \pm 0,009 / 1,12 \pm 0,06$ \\
\hline
\end{tabular}

Notes: in numerator - experiment, in denominator - control.

With early spring regenerating pruning and double application of mineral fertilizers, normal conditions are facilitated for the simultaneous growth of small and large plants during the growing year. On each pruned seedling, one bud awakens in growth, located closer to the root crown of the plant, but lateral shoots are not formed.

In the sowing plots, the inhibition growth of small plants is not observed and also there is no need to carry out much work of cutting (clean) the side shoots. Due to this, $91.0-99.1 \%$ of seedlings are preserved until the end of the growing season and their yield from 1 ha of the sowing plot makes 476.0-703.2 thousand pieces.

In the control variant under free growth without pruning, the development of seedlings occurred differently after overwintering. At $80-90 \%$ freezing three or four shoots sprouted on the base part over the soil; with partial freezing, the seedlings began to branch. On one plant, 5-11 lateral shoots formed, which delayed the growth of the main shoot and caused unfavorable condition for the normal growth of most stunted seedlings. In addition, sharp increase in summer temperature inside the sowing section made a depressing effect on small and stunted plants. As a result, in the year of growing, shaded plants gradually stopped growing and $30-39 \%$ of overwintered plants died. In the control, the yield of seedlings from 1 ha of the sowing section of plot depending on the hybrid combination constituted 283.0-498.6 thousand pieces, that is, 1.3 times less than in the experimental variant.

Due to the long growing season in the condition of Kashkadarya region, the summer sowing sections produce standard seedlings and nursery plants for the second year of cultivation. With spring (March 15) pruning of plants above soil level, the yield of nursery plants may constitute $59.8 \%$ (grade I-3.4\%; II-7.8\%; III$48.6 \%$ ), while seedlings make $40.2 \%$; without pruning (control), these indicators are respectively $40.3 \%(-;$ $8.0 \% ; 32.3 \%$ ), and $59.7 \%$.

\section{CONCLUSION}

According to the results of the five-year experiments, it was found that in medium-saline gray soils of Kashkadarya region in summer sowing plots, it is better to rejuvenate the seedlings with a proper pruning above the soil before the growing season (March). For this, it is recommended to apply mineral fertilizers in two terms on the basis of the rate of $240 \mathrm{~kg}$ of nitrogen, $90 \mathrm{~kg}$ phosphorus, and 45 potassium per ha. These agrotechnical measures allow to preserving 95.0$99.1 \%$ of overwintered plants and obtaining 441.0 to 717.8 thousand standard seedlings and nursery plants of mulberry from 1 ha of sowing section.

\section{REFERENCES}

1. Zhuraev M., Umarov Sh. R., Kholmatov D. I., Kuchkarov, U. (2010). Description of varieties, hybrids and forms of mulberry, created in the Republic of Uzbekistan and included in the world collection of mulberry. Tashkent, 2010, $4 \mathrm{p}$.

2. Zhuraev M., Umarov Sh. R., Kholmatov D. I., Kuchkarov U. (2010). Description of varieties, hybrids and forms of mulberry, created in the Republic of Uzbekistan and included in the world collection of mulberry. Tashkent, 2010, 5 p.

3. Kuchkarov U. (1987). High yield interlinear silkworm hybrids suitable for seasonal feeding. Scientific bases for the development of sericulture in Uzbekistan. Tashkent: SANIISH, $40 \mathrm{p}$.

4. Grebinskaya, M. I. (1950). Assessment of fodder merits of hybrid mulberry leaves on age-related morphological and structural features. Scientific bases for the development of sericulture in Uzbekistan. Tashkent: SANIISH, pp.11-45.

5. Zinkina S. S. (1981). Main criteria for the evaluation of mulberry varieties according to winter resistance. Materials from II All union seminar-meeting on genetics and breeding of silkworm and mulberry. Tashkent, pp. 29-31.

6. Pchelina N. A., Nazarova L. N. (1981). The results of breeding of feed mulberry in Ukraine. Materials from II All union seminar-meeting on genetics and 
breeding of silkworm and mulberry. Tashkent, pp.14-15.

7. Kuchkarov U. (1981). Perspective heterotic topcrossings of mulberry. Silk. №1. pp. 2-4.

8. Kuchkarov U., Kholmatov D., Akhmedova M. (2001). New regionized hybrids and perspective types of mulberry. Scientific bases for the development of sericulture in Uzbekistan. Tashkent: SANIISH, pp.5-8. 